\title{
Research on the Implementation of China's High-end Women's Clothing Brand ELLASSAY International Strategy
}

\author{
Mengyao Liu \\ Business School \\ Beijing Institute of Fashion Technology \\ Beijing, China
}

\author{
Hongzhong Shan \\ Business School \\ Beijing Institute of Fashion Technology \\ Beijing, China
}

\begin{abstract}
With the increase of national per capita income and the expansion of middle income group, more and more people have a higher pursuit of clothing, which requires for not only the improvement of comfort and the delicacy of tailoring, but also the design and brand value of clothing. The market development potential of high-end women's wear brand is huge, but it has been monopolized by foreign brands for a long time. A number of high-end women's clothing brands in China have gradually emerged and started to compete with foreign high-end brands for domestic and international markets. Shenzhen Gelisi Apparel Co., Ltd. (Hereinafter referred to as "ELLASSAY") is one of the outstanding representatives, determined to become "the leading brand of Chinese high fashion", and gradually grow into "the world's influential Chinese fashion brand" in the future. By means of transnational merger and acquisition, it opens the road of internationalization and provides reference for other domestic garment enterprises who want to realize internationalization by studying the motivation of internationalization and the implementation of transnational merger and acquisition strategy.
\end{abstract}

Keywords-ELLASSAY; Transnational merger and acquisition; strategy implementation

\section{INTRODUCTION}

Shenzhen Gelisi Apparel Co., Ltd. (Hereinafter referred to as "ELLASSAY"), whose main brand is Chinese high fashion brand ELLASSAY. Since its establishment in 1996, the brand has always followed the design style of "fashionable elegance". ELLASSAY (ELLASSAY) targets middle - and upper-income, elegant, fashionable, tasteful and mature urban middle class women aged from 25 to 40 years old. The brand of women's wear has been unique in its management thinking. When other enterprises stay in manufacturing and processing to earn a small profit margin, as early as 1996, it has the prospect of "leading brand of medium and high-end fashion in China". The company has five offline high-end clothing brands, namely ELLASSAY, LAUREL, Ed Hardy, IRO and VIVIENNE TAM, and an online haute couture brand, WITHSONG. It also owns $75 \%$ of baiqiu network and indirectly controls baiqiu e-commerce, a wholly-owned subsidiary of baiqiu network.

\section{A. Inner Growth Period from 1996 to 2015}

- Since its establishment in 1996, ELLASSAY has been deeply cultivating its brand. Since 2004, it has employed Mr. JEAN PAUL KNOTT, director of product research and development of YSL (saint Laurent) for 12 years and international fashion design master as the design consultant, which has greatly enhanced its brand image.

- In 2009, ELLASSAY and global private equity firm THE CARLYLE GROUP formally announced the formation of strategic alliance. Meanwhile, Carlyle's Asian growth fund, which focuses on growth companies, will inject $150 \mathrm{~m}$ into ELLASSAY. It is reported that through the establishment of strategic alliance, Carlyle investment will provide resources, management, culture, brand value added, marketing innovation and other all-round support for the company, to help the company achieve the goal of promotion to Chinese fashion leaders.

- ELLASSAY's spring/summer 2014 collection, titled "The City Light, "was released in September 2013 in Studio hall, the main venue of Lincoln Center fashion week in New York. As the first Chinese haute couture brand to participate in New York fashion week, ELLASSAY sparkles with New York City with its consistent confidence and quiet charm, demonstrating unique Chinese elegance. In November, we integrate into the international market again and sponsor the top model competition to expand its popularity overseas.

- In 2014, ELLASSAY was once again invited to attend New York fashion week. With its unique brand aesthetics, ELLASSAY has been praised for its elegance and delicate taste without losing femininity in independence.

\section{B. The Early Stage of Overseas Expansion Since 2015}

- On April 22, 2015, ELLASSAY was officially listed on the Shanghai stock exchange, and it was also the 
first Chinese brand to hold a fashion show on the stock exchange.

- In September 2015, it invested 11.18 million euros to acquire $100 \%$ equity of Dongming international investment (Hong Kong), owning the design, ownership and right to use Laurel, a German fashion brand owned by Laurel, in mainland China.

- In February 2016, it raised funds of 241 million through non-public offering, acquired $65 \%$ equity of Tangli international, acquired brand ownership of Ed Hardy in mainland China, Hong Kong, Macao and Taiwan, and increased its equity to $80 \%$ in April 2016.

- In June 2016, it paid 79 million to buy $16 \%$ of Shenzhen Qianhaishanglin investment management co., LTD (hereinafter referred to as " Qianhaishanglin ") shares of Fosun Changge, and obtained the controlling stake of French light luxury fashion brand IRO with a total of $65 \%$ stake.

- In August 2016, it purchased $75 \%$ of Baiqiu network with 277 million and indirectly controlled Baiqiu ecommerce, a wholly-owned subsidiary of Baiqiu network. It has the resources of international fashion brands such as Le Sportsac, ELLE and achette.

- In August 2017, the company acquired a 75\% stake in VIVIENNE TAM fashion house owned by Peony Power Limited for 7 million in cash, and acquired the ownership of the VIVIENNE TAM brand in mainland China.

\section{ANALYSIS OF THE CAUSE OF ELLASSAY INTERNATIONALIZATION}

\section{A. Entrepreneurship}

Entrepreneurship is an inexhaustible driving force for the continuous development of an enterprise. As a leader of ELLASSAY, Xia Guoxin has a keen insight into the market and a pragmatic and innovative entrepreneurial spirit. He not only pursues the development of the domestic market, but also advocates expanding the international market and lead the enterprise to go international.

\section{B. Enhancing Brand International Influence}

ELLASSAY is becoming a leading brand of high-end women's wear in China, but its recognition in the international market still needs to be improved. The acquisition of overseas famous brands by multinational companies can help enhance the visibility of enterprises, enhance the international influence of brands, and help enterprises to expand the global market.

\section{Optimization of Resource Allocation}

When enterprises enter foreign markets through foreign mergers and acquisitions, they can make full use of local resources to serve the development of enterprises and optimize the allocation of their own resources, give play to the synergistic effect of diversified industrial operations of enterprises and maximize the value of resources. On the one hand, enterprises use transnational mergers and acquisitions to enter the overseas market, which is conducive to more smooth development in the later stage. The main reason is that after the merger, the company can make full use of the platform, resource network and management advantages of the acquired company to better open up local market and reduce operational resistance.

\section{Young Consumers Pursue Individuality}

With the growth of the $80 / 90$ generation in China, a group of people aged from 25 to 35 years old, whose family career is gradually stable, and who have acquired certain consumption ability when entering the workplace, have become the main consumer force in China. With the rise of China's economy and its own awareness of pursuing uniqueness, quality and freedom, a number of young consumers full of personality and fashion sense are emerging, providing huge consumption demand for the development of light luxury clothing brands. In order to meet the changes in demand of the new generation of consumer groups, ELLASSAY needs to expand more brand possibilities on the basis of maintaining the tone of the main brand to cover more categories and a wider population.

\section{THE IMPLEMENTATION OF ELLASSAY 'S INTERNATIONALIZATION STRATEGY}

\section{A. Taking Example of Acquisition of IRO}

After going public in 2015, ELLASSAY officially started its road of internationalization and began to make a great deal of mergers and acquisitions, gaining strong momentum of growth through mergers and acquisitions. ELLASSAY is committed to building China's high-level fashion ecosystem and building a multi-brand matrix of fashion circle. With a clear m\&a strategy, the company has acquired four international light luxury brands in more than three years since its listing, including German high-end women's wear brand Laurel, American personalized light luxury brand popular logo EdHardy, French designer light luxury brand IRO and Chinese designer brand VIVIENNETAM. ELLASSAY layout of the brand tone difference is higher, the brand operating independent. ELLASSAY hopes to build a high fashion group through the international strategy of "endogenous growth + epitaxy m\&a" on the basis of making a good brand. Therefore, from 2015 to 2017, the company acquired a number of international fashion brands, which made the sub-brands and the company's performance constantly increase. At the same time, the main brand performance recovered, so that the company's revenue and net profit began to increase rapidly.

The most high-profile case was the acquisition of the French brand IRO. Next, this paper will focus on the m\&a process of this acquisition, in order to find out the characteristics of the implementation stage of ELLASSAY's international strategy from specific cases.

On June 28, 2016, ELLASSAY announced that it intends to purchase the $16 \%$ stake of former sea forest held by Fosun 
Changge by paying cash. Once the deal is completed, ELLASSAY will take a 65 percent stake of Qianhaishanglin, giving it a controlling stake. Qianhaishanglin holds 57 percent of ADONWORLD, while ADONWORLD holds 100 percent of IRO. Through this transaction, the company indirectly obtained the control of IRO through ADONWORLD.

\section{B. Acquisition Implementation Analysis}

- First of all, it's necessary to introduce the companies involved in this Merger and Acquisition case. Qianhaishanglin is a strategic investment platform established by ELLASSAY, Fosun Changge and Fosun Weishi. The importance of the platform is selfevident. Fosun Changge and Fosun Weishi both belong to Fosun group. Fosun group, founded in 1992, listed in Hong Kong in 2007 as a whole (0656 HK), to form the "insurance as the core of comprehensive financial capacity" and "rooted in China, the global industry consolidation" two-wheel driven global investment group. As of December 31, 2017, the total assets of Fosun group reached 530 billion, has a good ability of investment and investment resources, investment in happy fashion has a profound experience, such as successfully invested Greece jewelry brand FolliFollie, the famous American highend women's clothing brand st. John and high-end custom Italian men's Caruso, etc. ELLASSAY selected Fosun group as a partner, it is took a fancy to Fosun rich experience in the field of overseas mergers and acquisitions. ADONWORLD owns a 100\% stake in the acquired party IRO Company. IRO SAS company headquartered in Paris, France, is a clothing design and sales company, November 26, 2010, IRO company set up in Paris, France, shareholders for ELYONE and AEL.IRO has a subsidiary in the UK, Germany, Italy, Spain, Denmark, the United States, China, it also has a distribution network in the main developed countries and regions around the world, its brand "IRO" brand aims to create excellent quality of daily costume and create concise and natural taste. Through the adoption of the old leather, wool and silk, etc., make a street punk style series design combined with Paris fashion inspiration. IRO is a designer brand which position in the light of luxury, high-end leisure brand, main fashion women's clothing products, the design concept for "street girls \& fashion able women", pursue the street mood French contracted style.

- Secondly, we should sort out the events before and after the merger. On May 6, 2016, when Qianhaishanglin was established, the original capital contribution) structure was composed of three companies: ELLASSAY, Fosun Changge and Fosun Weishi, which contributed $65 \%, 25 \%$ and $10 \%$ respectively. From the very beginning, ELLASSAY was the controlling shareholder of Qianhaishanglin. Fosun Changge and Fosun Weishi of Fosun group were only the management and risk control side. By
May 13, however, it had changed its plan, announcing that it would transfer $16 \%$ of its shares to Fosun Changge for one yuan, leaving it with $49 \%$. As a result, Fosun group became the Qianhaishanglin absolute holding control. Then, on June 21, French newspaper Les Echos reported a report: Fosun group defeated LVMH in the bidding for the stake of IRO and succeeded in holding the company. But on June 28th, as everyone cheered Fosun's victory, it announced plans to use $\$ 79 \mathrm{~m}$ in cash to buy a $16 \%$ stake in the Qianhaishanglin company. When the deal is completed, it will return as the controlling shareholder of Qianhaishanglin with a 65 percent stake. Through the strategic platform of Qianhaishanglin, ELLASSAY holds a 57 percent stake in ADONWORLD, and thus indirectly gets a 100 percent stake in the company of IRO of ADONWORLD.

- Finally, do a summary about the merger. The capital operation is a win-win situation. On the one hand, Fosun group received 79 million cash, on the other hand, ELLASSAY get the control stake of IRO and a large number of international resources, the most precious thing are that ELLASSAY gets the capital operation experience. In this battle, competition is the world's biggest luxury group LVMH, and ELLASSAY, is a rising China's high-end brand, and don't have much experience of transnational m\&a, however the project resources and overseas m\&a experience of Fosun group is rich, Fosun fund and its management has invested many overseas consumer brands, including the famous Greek fashion brands group FolliFollie high-end women's clothing brand, the famous American st. John, high-end custom Italian men's Caruso, fashion life brand TomTailor, etc. Fosun group have strong capital strength, much overseas m\&a project resources and experience, Fosun Changge is focusing on investment in the fashion industry and related Internet companies. The strength, experience and even fame of Fosun apparently play a positive role. Without a $16 \%$ equity deal, it is hard to say how likely it would be to beat LVMH, the world's biggest luxury goods group, by itself. After the merger and acquisition, ELLASSAY and Fosun group can realize resource sharing and investment discussion, actively explore and find important investment projects suitable for ELLASSAY in the global fashion industry, and achieve the company's business expansion and continuous profit growth. Through this endeavor, the team of ELLASSAY not only learned the operating experience before the transnational merger and acquisition from the fosun group, but also gained the management experience after investment through the sharing platform.

\section{CONCLUSION}

The extensional internationalization strategy of ELLASSAY mainly through mergers and acquisitions to 
build more brand fashion matrix and by means of capital group, established the strategic investment platform, through resource sharing and investment discuss to carry out the transnational merger and acquisition investment. By 4 times of overseas mergers and acquisitions in recent years, ELLASSAY in the process of collectivization development, the insight of screening brand resources and the operation ability to develop brand have improved. When domestic garment enterprises adopt the strategy of transnational merger and acquisition, they can learn from the experience of ELLASSAY and choose the right enterprise to establish strategic alliance based on their own actual situation, so as to achieve win-win results by virtue of the capital group.

\section{ACKNOWLEDGMENT}

R. B. G. thanks to my teacher Shan Hongzhong, an associate professor, and especially thanks for his constructive advice and patient guidance. From the confusion in the topic selection to the problems in the first draft, the mentor was extremely patient and diligent in giving guidance. Whenever there are various problems, my mentor always patiently corrects and explains them to me in his busy schedule, and constantly encourages and helps me to correct the problems and improve the quality of the paper. He cares about the details. The preciseness and seriousness of a mentor and the profound knowledge of a mentor make me realize the superficiality of my knowledge and the superficiality of my cognition. I feel lucky to be able to learn from Mr. Shan. Here I would like to express my most sincere respect and thanks to Mr. Shan!

\section{REFERENCES}

[1] Liu Jianchang, "Strategic thinking on building international brand in China's garment industry," Northern Economy. 2007(12).

[2] Pang Chen and Li Xiaofen, "Path selection of domestic clothing brand internationalization strategy combinations," Business and management. 2014(07).

[3] Peng Chao,Zhu Xianni, "ELLASSAY: China's high-end clothing leader," Shanghai Securities News. 2015 (A10).

[4] Lu Yan, "ELLASSAY 's merger is ferocious and secret," Chinese Times. 2016(013)

[5] Zhen Zhen, "From Mass Phil to ELLASSAY, the domestic women's clothing get through the close siege," China Textile. 2016(2). 